\title{
CLASSIFICATION OF STREPTOCOCCI BASED ON THE CORRELATION OF RESULTS OF HEMOLYTIC, FERMENTATIVE AND PRECIPITIN TESTS
}

\author{
W. H. B A R ES
}

From the Department of Pathology and Bacteriology, University of California, Berkeley, Cal.

In the literature correlation of the hemolytic, fermentative, and serological reactions of streptococci has yielded little of practical value. In the hands of different investigators similar strains have produced varying correlated results.

\section{Hemolytic Reactions}

Since the discovery of streptococcus hemolysins by Marmorek ${ }^{1}$ in 1902, many questions bearing on this phase of streptococci have been investigated and hemolysis has been made a basis for their classification by Schotmüller." The blood of many species of animals has been tried. ${ }^{3}$ In general three preparations of blood have been used, namely, unwashed defibrinated blood, washed red blood cells, and a combination of fresh blood with various mediums. Besredka ${ }^{3}$ was one of the early workers to investigate the hemolytic effects of streptococci, and experiments with the blood of man, goat, sheep, goose, and chicken, obtaining no results with the last two. M'Leod" established a minimum hemolytic dose with washed red blood cells of the ox. Lyall ${ }^{\mathrm{s}}$ classified streptococci according to their metabolic gradients and correlated the results with their hemolytic effect on washed red blood cells of the sheep. He showed the advantage of using constant amounts of the washed corpuscles (a 5\% suspension) over that of blood agar. Blake ${ }^{6}$ showed that S. viridans, considered nonhemolytic by Holman, produces methemoglobin by adding equal amounts of the culture grown in ascitic broth to a $5 \%$ suspension of washed sheep corpuscles.

The most common method of demonstrating the hemolytic properties of streptococci is to cultivate them on nutrient agar to which has been added a small quantity (5\%) of freshly drawn blood, as shown by Baerthlein, ${ }^{8}$ Becker, ${ }^{\circ}$ Benthin, ${ }^{10}$ Cole, ${ }^{11}$ Conrad, ${ }^{12}$ Davis, ${ }^{13}$ Levy, ${ }^{14}$ Rosenow, ${ }^{15}$ and Van

Received for publication March 4, 1919.

1 Ann. de l'Inst. Pasteur, 1902, 16, p. 172.

2 München. med. Wchnschr., 1903, 20, p. 894.

3nn. de l'Inst. Pasteur, 1901, 15, p. 880.

4 Jour. Path. and Bacteriol., 1911, 12, 16, p. 321.

Jour. Med. Research, 1914, 30, p. 515 and p. 487.

- Jour. Exper. Med., 1916, 24, p. 4.

7 Jour. Med. Research, 1916, 34, p. 377.

8 Centralbl, f. Bakteriol., I, O., 1914, 74, p. 201.

a Jour. Infect. Dis., 1916, 19, p. 754.

${ }^{10}$ Centralbl. Bakteriol. I, O., 1912, 67, 1883, p. 92.

11 Jour. Exper. Med., 1914, 20, p. 363.

12 Beitr. z. Geburtsh. u. Gynak., 1909, 13, p. 364.

18 Jour. Infect. Dis., 1917, 21, p. 308.

14 Virchows Archiv, 1907, 187, p. 327.

15 Jour. Am. Med. Assn., 1914, 14, p. 1. 
Logham. ${ }^{16}$ Schotmüller, ${ }^{2}$ using human blood agar, divided streptococci into three classes: those giving a clear colorless zone around the colonies-S. pyogenes; those producing a green colony-S. mitior seu viridans, and small mucoid colonies with a dark green zone around the colonies in hemoglobin medium-S. mucosus. Libman ${ }^{17}$ described a series of concentric hemolytic zones from the action of streptococci on blood agar, and Ruediger ${ }^{18}$ discussed the changes produced on blood in blood agar by bacteria. He decided that the green coloration was due to lactic acid in combination with blood and glucose. Benthin, ${ }^{10}$ using 13 strains of streptococci, showed that glucose added to blood agar inhibited hemolysis. Braun ${ }^{19}$ determined hemolysin producers by growing streptococci on rabbit blood agar. Van Logham, ${ }^{16}$ using V. El Tor and Vibrio cholerae, differentiated between hemolysis as shown by a bright halo around colonies on blood agar plates, and hemodigestion shown by a green coloration around the colonies on the same plate. Baerthlein described three different changes by bacteria: (1) simple hemolysis in which the hemoglobin is extracted leaving the stroma preserved, occurring in fluid medium; (2) hemoglobin digestion in which blood pigments are completely destroyed with stroma unaffected, and (3) hemodigestion in which both pigment and stroma are destroyed. Rosenow claimed to have changed the hemolytic and virulent properties of streptococci by growing them symbiotically with B. subtilis on blood agar. Becker ${ }^{\ominus}$ recognized the necessity of a standardized grade of blood agar and found that hemolysis was inhibited by dextrose. Davis, ${ }^{13}$ on the other hand, claimed that dextrose did not hinder hemolysis. His observation thus differed from that of Benthin's and Becker's. This was probably due to the fact that Benthin and Becker failed to differentiate between the action of hemolysins and that of acid on the mediums.

\section{Virulence in Relation to Hemolysis}

Marmorek ${ }^{1}$ first called attention to a possible relation between hemolytic activity and virulence by stating that the more virulent the strain the more quickly it dissolves the red blood corpuscles in the host. Schotmüller, ${ }^{2}$ making his classification of streptococci on their hemolytic effects, did not believe, however, that the virulence of certain strains was related to their hemolytic reactions. Likewise de Waele and Sugg ${ }^{21}$ concluded that the hemolytic reac. tions of streptococci are not proportional to their virulence. Fromme, ${ }^{22}$ working with streptococci isolated from the peritoneum after laparotomy, assumed a neutral attitude as to relation of hemolysis to pathogenesis. Zangmeister, ${ }^{23}$ growing streptococci on human blood agar plates, decided that there is no relation between hemolytic actions and virulence; however, after examining a large number of cases, he observed that $73 \%$ of puerperal women harboring hemolytic streptococci gave a temperature reaction, while of those harboring nonhemolytic streptococci only $12 \%$ showed rise in temperature. Braun ${ }^{18}$ obtained varying results depending on the incubation period of the organisms, the amount of inoculum, and the animals infected. $\mathrm{M}^{\prime} \mathrm{Leod}^{\mathrm{*}}$ found that by

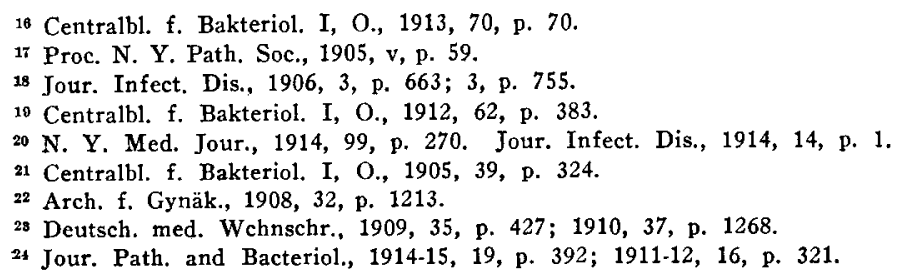


using constant methods the degree of hemolysis of streptococci in vivo was related to virulence but that the results were not as constant as when the organisms were grown on blood agar. Davis ${ }^{25}$ concluded that since hemolytic streptococci are so prone to attack serous surfaces they should be suspected as virulent agents in the causation of disease. Lyall ${ }^{5}$ observed a definite relationship between hemolysis and virulence, and he believes that there is a relation between their solubility in bile and their virulence. Rosenow observed a direct relationship between hemolytic streptococci and acute streptococcal infections, while chronic streptococcal infections were more closely associated with the viridans type. Holman ${ }^{7}$ believes that, since the majority of streptococci producing pyogenic infections are hemolytic and those of a nonhemolytic power produce less acute diseases, the property of hemolysis in relation to virulence should be recognized.

\section{Fermentattve Reactions}

Winslow, ${ }^{22}$ classifying streptococci according to their action on carbohydrates, suggested the possibility of a metabolic gradient. He showed that there were three specific strains: those fermenting monosaccharids only; those fermenting monosaccharids and disaccharids, and those fermenting monosaccharids, disaccharids and trisaccharids. Walker ${ }^{28}$ found that on cultivation and inoculation in white mice, streptococci gave varying fermentative reactions in the same sugars. Holman ${ }^{28}$ obtained specific and constant results with Hiss serum water medium and Andrade's indicator. $\mathrm{He}$ used lactosea disaccharid; mannite-an alcohol, and salicin-a glucosid. Thro, ${ }^{80}$ using dextrin, arabinose, mannite, salacin, raffinose, lactose, saccharose and inulin with litmus indicator, failed to secure uniform results.

\section{ImMUNOLOGICAL Reactions}

Kinsella and Swift, ${ }^{31}$ examining nonhemolytic streptococci for specificity of complement fixation, obtained overlapping but apparently related results. In some reactions the antigen was specific for one serum while in others the serum was fixed by several antigens. They explain their results by saying that some streptococci have a more complex chemical nucleus than others. Howell, ${ }^{32}$ working with strains of nonhemolytic streptococci from specific disease finds that there is a tendency for them to react alike in complement fixation. Aschner ${ }^{33}$ obtained marked fixation with the homologous antigen and a positive but less marked fixation with mixed antigen.

Since Bordet observed agglutination of cholera vibrios by immune serum, many have tried to correlate the various cultural relationships of streptococci with agglutination (Besredka, ${ }^{34}$ Dick, ${ }^{35}$ Floyd and Wolbach, ${ }^{36}$ Hiss, ${ }^{37}$ Kligler, ${ }^{38}$

${ }^{25}$ Arch. Int. Med., 1912, 9, p. 505.

26 N. Y. Med. Jour., 1914, 99, p. 270, and Jour. Infect. Dis., 1914, 14, p. 1.

2i Jour. Infect. Dis., 1912, 10, p. 285.

28 Proc. Roy. Soc., B., 1912, 85, p. 400.

20 Jour. Infect. Dis., 1914, 15, p. 208; Jour. Med. Research, 1916, 34, p. 377.

30 Jour. Infect. Dis., 1914, 15, p. 234.

${ }^{31}$ Jour. Exper. Med., 1917, 25, p. 877.

${ }^{32}$ Jour. Infect. Dis,, 1918, 22, p. 230.

38 Jour. Infect. Dis., 1917, 21, p. 409.

s4 Ann. de l'Inst. Pasteur, 1904, 18, p. 363, and p. 373.

as Jour. Infect. Dis., 1913, 12, p. 111.

${ }^{36}$ Jour. Med. Research, 1913, 14, 29, p. 493.

37 Jour. Exper. Med., 1905, 7, p. 547.

38 Jour. Infect. Dis., 1915, 16, p. 327. 
Krumwiede and Valentine ${ }^{38 a}$, but with no marked success. Swift and Thro ${ }^{39}$ obtained specific reactions for group classification of streptococci, but not for specific strains, by complement fixation and conglutination. Wolbach ${ }^{40}$ comparing his agglutination and fermentation reactions obtained promising results which, although not specific enough for a group classification, warranted the belief that streptococci might be classified into fewer groups.

My own work shows the feasibility of employing the precipitin reaction successfully in the grouping of streptococci and that the serological distinctions are correlated with cultural differences. Kraus ${ }^{41}$ showed that when the germ-free filtrates of cultures of cholera, typhoid, and plague bacilli are mixed with their respective serums, a precipitate is formed. Tchistowitch ${ }^{42}$ speaks of Marmorek as the first to report a streptococcic precipitin. Gay and Chickering ${ }^{43}$ made use of the precipitin reaction in the concentration of the protective bodies in antipneumococcus serum. Blake, ${ }^{4+}$ by a simpler method for obtaining precipitinogen, established an efficient precipitin test for the diagnosis of different types of pneumonia.

\section{METHODS USED IN STUDY OF HEMOLYSIS AND FERMENTATION OF STREPTOCOCCI}

The purpose of this investigation was to attempt to correlate if possible the hemolytic, fermentative, and precipitin reaction of certain strains of streptococci. Fifty-one strains were chosen, isolated from various sources as follows : 18 from sputum; 4 from infected tonsils; 3 from pyorrhea; 1 from empyema; 1 from gastric ulcer; 1 from the heart blood in a case of nephritis; 1 from a blood culture in septicemia ; 1 from heart blood in leukemia; 1 from feces; 7 from urethral discharges; 1 from urine; 2 from blood cultures in cases of epilepsy; 1 from cervix of uterus; 5 from nose and throat swabs in cases of colds; 2 from sources unknown; 1 from abscess in guinea-pig, and 1 from an infection in a horse, disease unknown.

These cultures were examined for hemolysis simultaneously by three different methods: by inoculation into a $5 \%$ suspension of rabbit corpuscles; by growing them on rabbit blood sugar-free agar, and by growing them on rabbit blood nonfermented agar. The mediums were made as follows :

1. Rabbit Blood Sugar-Free Agar: Ground bob veal, $500 \mathrm{gm}$; tap water, $700 \mathrm{cc}$; boiled 5 minutes; strain through a tin strainer; rinse with tap water q. s., to $1,000 \mathrm{cc}$; transfer to a clean kettle and boil; strain through cheese cloth; adjust to +1.0 ; sterilize in Erlenmeyer flaskes'at $100 \mathrm{C}$. for 2 hours;

\footnotetext{
ska Jour. Infect. Dis., 1916, 19, p. 760.

s9 Arch. Int. Med., 1911, 7, p. 24.

to Jour. Med. Research, 1914, 29, p. 493.

41 Wien. klin. Wchnschr., 1897, 10, p. 736.

12 Ann. de l'Inst. Pasteur, 1899, 13, p. 406.

4 Jour. Exper. Med., 1915, 21, 4, p. 389.

4 Ibid., 1917, 36, p. 67.
} 
inoculate with $\mathrm{B}$. coli communis and incubate 24 hours at $37 \mathrm{C}$; t transfer to a suitable pan and boil 10 minutes; restore to original quantity by adding distilled water. Add: peptone, $1 \% ; \mathrm{NaCl}, 0.5 \%$. Add: Japanese agar, 3\%; readjust to +1.0 phenolphthalein; sterilize in Erlenmeyer flasks at $10 \mathrm{lbs}$. for 1 hour; cool to $45-42$ C. Add: $7.2 \%$ sterile rabbit blood; tube or draw into petri dishes sterilly; incubate 24 hours for contamination tests.

2. Rabbit Blood Nonfermented Agar: Bob veal, $500 \mathrm{gm}$; ; tap water, 700 c c; boil 5 minutes; strain through a tin strainer; rinse with tap water q. s., to $100 \mathrm{cc}$; transfer to a clean kettle. Add: peptone (Digestive Ferments Co.), $1 \% ; \mathrm{NaCl}, 0.5 \%$; titrate and adjust to $+1.0 \%$. Add: dissolved Japanese agar, $3 \%$; readjust to +1.0 ; sterilize 1 hour at 10 lbs. Add: sterile rabbit blood, $7.5 \%$; tube about $10 \mathrm{cc}$ per tube; incubate the tubes for 24 hours at $37 \mathrm{C}$.

\section{TABLE 1}

Streptococci Studied, Classified According to Hemolysis and Fermentation

\begin{tabular}{|c|c|c|c|}
\hline $\begin{array}{l}\text { Hemolytic } \\
\text { Reaction }\end{array}$ & $\begin{array}{l}\text { Classification of Cultures } \\
\text { by Hemolytic and } \\
\text { Fermentation Tests }\end{array}$ & $\begin{array}{l}\text { Number } \\
\text { of } \\
\text { Cultures }\end{array}$ & Source of Cultures \\
\hline \multirow{5}{*}{ Hemolytic } & S. infrequens & $\begin{array}{l}6 \\
1 \\
3 \\
1 \\
1 \\
4 \\
1 \\
1 \\
1 \\
1 \\
1\end{array}$ & $\begin{array}{l}\text { Sputum } \\
\text { Gastric uleer } \\
\text { Tonsils } \\
\text { Heart blood in nephritis; necropsy case } \\
\text { Urethra } \\
\text { Empyema } \\
\text { Cervix uterus } \\
\text { Nasal swab } \\
\text { Guinea-pig, infected joint } \\
\text { Source unknown }\end{array}$ \\
\hline & S. pyogenes & $\begin{array}{l}1 \\
1 \\
1 \\
1 \\
1\end{array}$ & $\begin{array}{l}\text { Tonsils } \\
\text { Urethra } \\
\text { Gums in pyorrhea } \\
\text { Sputum } \\
\text { Blood culture; epilepsy }\end{array}$ \\
\hline & S. anginosus & $\begin{array}{l}1 \\
5\end{array}$ & $\begin{array}{l}\text { Epilepsy, throat swab } \\
\text { Sputum }\end{array}$ \\
\hline & S. subacidus & $\begin{array}{l}1 \\
2 \\
1 \\
1\end{array}$ & $\begin{array}{l}\text { Septicemia blood culture } \\
\text { Sputum } \\
\text { Empyerna pus } \\
\text { Veterinary; source not known }\end{array}$ \\
\hline & S. hemolyticus No. 2 & 1 & 'Throat swab \\
\hline \multirow{6}{*}{ Nonhemolytic } & S. fecalis & $\begin{array}{l}1 \\
1\end{array}$ & $\begin{array}{l}\text { Throat swab } \\
\text { Sputum }\end{array}$ \\
\hline & S mitis & $\begin{array}{l}2 \\
1 \\
1\end{array}$ & $\begin{array}{l}\text { Sputum } \\
\text { Human feces } \\
\text { Leukemia; heart blood; neeropsy case }\end{array}$ \\
\hline & S. nonhemolyticus No. 2 & 1 & Pyorrhea \\
\hline & S. ignavus & $\begin{array}{l}1 \\
1\end{array}$ & $\begin{array}{l}\text { Unknown } \\
\text { Pyorrhea }\end{array}$ \\
\hline & s. equinus & 3 & Urethral \\
\hline & S. salivarius & $\begin{array}{l}1 \\
1\end{array}$ & $\begin{array}{l}\text { Throat swab } \\
\text { Nasal swab }\end{array}$ \\
\hline
\end{tabular}

The blood agar was drawn into petri dishes. The stock cultures were maintained on rabbit blood nonfermented agar, and in tubes containing $1 \mathrm{c} \mathrm{c}$ of defibrinated blood. Cultures, when properly sealed, 
may be kept alive from 10-12 months or even longer, in defibrinated blood at room temperature.

Table 1 shows the classification of the streptococci based on hemolysis in the $5 \%$ suspension of rabbit corpuscles and on a modification of Holman's ${ }^{45}$ fermentative mediums, described later. It was noted that the incubation of streptococci in a suspension of red blood cells was a more delicate method of testing hemolysis than growth on blood agar. The readings for hemolysis in table 1 represent observations made at the end of 4 hours' incubation, observations being made every 15 minutes beginning at the end of the first 10 minutes. The rapidity with which hemolysis took place varied with different cultures.

Hemolytic streptococci gave three different and distinct changes in the washed corpuscles. Some of them produced a laking of the corpuscles without digestion of the stroma; another series laked the corpuscles and then changed the hemoglobin to a brown color (methemoglobin) without digestion of the stroma, while the third attacked the corpuscles so violently that there was no apparent intermediary stage, that is, laking of blood, but an oxidation to methemoglobin with the digestion of the stroma of the cell as explained by Ruediger. ${ }^{46}$. These when grown on blood agar produced a green pigmentation and would thus be classed as Strep. viridans (nonhemolyzers).

A comparison of the hemolytic reactions on the sugar-free and the regular unfermented blood agar showed no wide differentiation. Tests. were made with the hemolytic strains to determine the effect of dextrose on their hemolytic powers in blood agar. Blood agar containing. $0.5,1,1.5$ and $2 \%$ glucose was used. No hemolytic inhibition could be observed by the cultures tried until an addition of over $1 \%$ dextrose was used.

Increasing the glucose content of the blood agar medium increases. the amount of green pigment produced by the viridans group of streptococci. This observation has been reported by Ruediger. ${ }^{46}$ Some of the nongreen producers on sugar-free blood agar when grown on a 1 or $2 \%$ dextrose blood agar produced a green pigment-a fact which agrees with Crowe' ${ }^{47}$ and Sullivan's ${ }^{48}$ observations.

Three tests of the fermentative reactions were carried out at intervals of 3 months with constant results. Extreme care was taken tor

45 Jour. Med. Research, 1916, 34, p. 377.

46 Jour. Am. Med. Assn., 1903, 41, p. 962; Jour. Infect. Dis., 1906, 3, p. 663.

17 Lancet, 1913, 1, p. 611.

4 Jour. Med. Research, 1905-06, 9, p. 109. 
conduct them under identically the same conditions, using a modification of Holman's method with $1 \%$ solutions of salicin, mannite, and lactose in carbohydrate-free broth with Andrade's indicator. It will be seen that carbohydrate-free broth was substituted for Hiss serum water, used by Holman. Both methods were tried, but the carbohydrate-free broth was used, since it gave equally as good results and was simpler and cheaper to make.

\section{CLASSIFICATION BY MEANS OF HEMOLYTIC AND FERMENTATIVE CORRELATIONS}

Following this procedure and correlating the results, the 51 strains fell into 11 groups shown in table 1 as follows: 20 strains of $S$. infrequens; 5 of S. pyogenes; 6 of S. anginosus; 6 of S. subacidus; 1 of S. hemolyticus No. $2 ; 2$ of S. fecalis; 4 of S. mitis; 1 of S. nonhemolyticus; 2 of S. ignavus; 3 of S. equinus, and 1 of S. salivarius. Judging from the number of actual strains in each group, a matter to which Blake called attention, $\mathrm{S}$. infrequens could not be considered of minor importance in this series of cultures. Fifty-one strains, however, are probably too small a series for making such general statements.

\section{METHOD OF IMMUNIZATION}

The next step was to secure serum for correlating the two previous results with that of a precipitin test. Eight cultures were chosen and rabbits immunized against the cultures, respectively, as follows:

\section{Hemolytic Type}

Rabbit $1-\mathrm{S}$. infrequens culture No. 3 Rabbit 2--S. pyogenes culture No. 2 Rabbit 3-S. anginosus culture No. 11 Rabbit 4-S. subacidus culture No. 1 Rabbit 6-S. hemolyticus No. 2 culture No. 26

The cultures for immunizing were incubated in $20 \mathrm{cc}$ of a $1 \%$ glucose veal infusion broth for 24 hours in contrast to Bordet's ${ }^{49}$ method of adding ascitic fluid to broth. The growth was centrifugalized in the same tube as grown, the supernatant fluid discarded, and the sediment re-suspended in $3 \mathrm{cc}$ of salt solution. At first, $1 \mathrm{cc}$ of the suspension was injected subcutaneously over the abdomen every week for 6 weeks. In a few cases the rabbits succumbed to infection,

49 Ann. de 1'Inst. Pasteur, 1897, 11, p. 177. 
notably the first 2 rabbits started on $S$. infrequens. This result contrasts sharply with those of Pasquale,,$^{50}$ who observed that short chained streptococci were nonpathogenic. The culture I used in this case was isolated from a gastric ulcer. There were no signs of gastric ulcer in the rabbits after death nor were there any signs of localized lesions except at the point of inoculation; for contrary to results see Rosenow ${ }^{51}$ and Thalmann. ${ }^{52}$ These inoculations were followed by weekly intraperitoneal doses for 6 weeks with $2 \mathrm{cc}$ of a $5 \mathrm{cc}$ suspension grown in $20 \mathrm{c} \mathrm{c}$ of broth as described, and by subsequent intravenous doses of $2 \mathrm{cc}$ of suspension given daily for 3 days. After an intermission of 3 days the intravenous inoculations were repeated until four such courses were given. Ten days subsequently the rabbits were bled from the heart, about $40 \mathrm{cc}$ of blood being drawn aseptically from each rabbit and allowed to clot. The serum from these bleedings was pipetted off aseptically into sterile containers.

\section{PRECIPITIN TESTS}

The serum thus obtained was used in determining the precipitinogen content of the supernatant broth from the 51 strains of streptococci after 48 hours' incubation at $37 \mathrm{C}$. Two methods were tried, namely, that used by Gay ${ }^{53}$ in connection with the pneumococcus, and the addition of the diluted antiserum directly to the undiluted supernatant broth from the centrifugalized culture as followed by Blake. ${ }^{44}$ In this work the latter method gave the better result and was therefore chosen. Constant amounts $(1 \mathrm{cc}$ ) of clear undiluted supernatant broth antigen were added to equal amounts of diluted rabbit antistreptococcus serum. Both homologous and heterologous mixtures were made. Controls consisting of the supernatant broth antigen added to normal rabbit serum, also of normal uncultured broth added to rabbit antistreptococcus serum were made. The following dilutions of serum were made: $1: 50 ; 1: 100 ; 1: 200 ; 1: 400 ; 1: 800$; $1: 1,600$, and $1: 3,200$. The mixtures were placed at $37 \mathrm{C}$ for from $8-10$ hours, then removed to the icebox for 2 hours. In most cases flocculent precipitates were formed in the homologous combinations of the highest dilutions. Heterologous combinations also gave pre-cipitates but few reacted above dilutions of $1: 200$. Controls showed

\footnotetext{
50 Ziegler's Beit. Z Path. Anat., 1893, 12, 433, p. 499.

${ }^{51}$ N. Y. Med. Jour., 1914, 99, p. 270.

32 Centralbl. f. Bakteriol. I, O., 1912, 46, p. 406.

ss Jour. Exper. Med., 1915, 21, p. 389.
} 
no evidence of precipitate formation. The results (compare table 2) show that specific precipitins were formed, also group precipitins, since in many cases precipitates developed when heterologous combinations of antiserums and antigen were made. Sterility tests were carried out to eliminate the possibility of the precipitate being a bacterial growth.

To some of the immune serum $0.3 \%$ tricresol was added. This very seriously interferred with the precipitin reaction, so much so that in serum 2, there was not enough to make a complete test with all of the heterologous precipitinogens. In this case the rabbit died after a small bleeding so that no more serum could be obtained.

\section{DISCUSSION}

Fifty-one strains of streptococci, isolated from various sources, were examined and classified according to the correlation of their hemolytic, fermentative and precipitinogen properties. Their hemolytic properties were best shown by incubating them for 4 hours at $37 \mathrm{C}$. in a $5 \%$ normal suspension of rabbit corpuscles in salt solution. Two general types were recognized-hemolytic and nonhemolytic. The hemolytic streptococci gave three different varieties of hemolysis. Some of them produced laking of red blood cells without digestion of the stroma, others produced laking followed by methemoglobin formation without stroma digestion, while a third class produced methemoglobin without previous laking, but with stroma digestion. This last type according to Holman ${ }^{54}$ is classified as nonhemolytic when grown on regular blood agar. The nonhemolysers had no apparent effect on the red blood corpuscles. Sugar-free blood agar showed no green pigment producers, but when many of the strains corresponding to the nonhemolysers were grown on the nonfermented blood agar, or on blood containing up to $2 \%$ glucose, the green pigment increased in proportion. Hemolytic strains were more frequently associated with acute infectious diseases than the nonhemolytic. The 51 cultures of streptococci were divided into 11 different strains by the correlation of their hemolytic and fermentative test.

The serological investigations consisted in immunizing eight rabbits with one each of 8 of 11 strains and testing the immune serums for their precipitin properties. The rabbits responded by producing antiserum containing specific precipitins as well as group precipitins.

84 J. Med. Res., 1916, 34, p. 377. 
TABLE 2

Showing Highest Antiserum Dilution with Positive Precipitin Reaction

\begin{tabular}{|c|c|c|c|c|c|c|c|c|}
\hline \multirow{2}{*}{$\begin{array}{c}\text { Culture } \\
\text { Number of } \\
\text { Preeipl- } \\
\text { tinogen }\end{array}$} & \multicolumn{8}{|c|}{ Name of Antiserum } \\
\hline & $\begin{array}{l}\text { Infre- } \\
\text { quens } \\
\text { (1) }\end{array}$ & $\begin{array}{c}\text { Pyog- } \\
\text { enes } \\
\text { (2) }\end{array}$ & $\begin{array}{c}\underset{\text { sus }}{\text { Angino- }} \\
\text { (3) }\end{array}$ & $\begin{array}{l}\text { Sub- } \\
\text { acidus } \\
\text { (4) }\end{array}$ & $\begin{array}{l}\text { Hemo- } \\
\text { lytie } \\
\text { No. } 2 \\
(5)\end{array}$ & $\begin{array}{c}\text { Fecalis } \\
(6)\end{array}$ & $\begin{array}{c}\text { Mitis } \\
\text { (7) }\end{array}$ & \begin{tabular}{|c} 
Nonhem- \\
olytic \\
No. 2 \\
(8)
\end{tabular} \\
\hline $\begin{array}{c}\text { S. infrequens } \\
3 \\
4 \\
5 \\
6 \\
15 \\
16 \\
21 \\
22 \\
30 \\
35 \\
36 \\
37 \\
38 \\
41 \\
43 \\
44 \\
45 \\
46 \\
50 \\
51\end{array}$ & \begin{tabular}{|c|}
$1: 3,200$ \\
$1: 3,200$ \\
$1: 3,200$ \\
$1: 3,200$ \\
$1: 1,600$ \\
$1: 3,200$ \\
$1: 3,200$ \\
$1: 800$ \\
$1: 3,200$ \\
$1: 3,200$ \\
$1: 400$ \\
$1: 3,200$ \\
$1: 3,200$ \\
$1: 1,600$ \\
$1: 3,200$ \\
$1: 3.200$ \\
$1: 3,200$ \\
$1: 3.200$ \\
\end{tabular} & $\begin{array}{c}1: 100 \\
1: 100 \\
1: 100 \\
\\
1: 100 \\
0 \\
\\
1: 100 \\
1: 100 \\
1: 800 \\
1: 200 \\
1: 200 \\
1: 100\end{array}$ & $\begin{array}{l}1: 50 \\
1: 50 \\
1: 50 \\
1: 50 \\
1: 100 \\
1: 100 \\
1: 50 \\
1: 50 \\
1: 50 \\
1: 50 \\
1: 50 \\
1: 50 \\
1: 50 \\
1: 50 \\
1: 200\end{array}$ & $\begin{array}{l}1: 100 \\
1: 100 \\
1: 400 \\
1: 100 \\
1: 200 \\
1: 200 \\
1: 100 \\
1: 200 \\
1: 1,600 \\
1: 200 \\
1: 200 \\
1: 200 \\
1: 200 \\
1: 400 \\
1: 200 \\
1: 200 \\
1: 400 \\
1: 200 \\
1: 400 \\
1: 400\end{array}$ & $\begin{array}{l}1: 50 \\
1: 50 \\
1: 50 \\
1: 50 \\
1: 50 \\
1: 50 \\
1: 100 \\
1: 50 \\
1: 50 \\
1: 100 \\
1: 100 \\
1: 50 \\
1: 50 \\
1: 50 \\
1: 100 \\
1: 100 \\
1: 200 \\
1: 100 \\
1: 800 \\
1: 200\end{array}$ & $\begin{array}{l}1: 200 \\
1: 200 \\
1: 200 \\
1: 200 \\
1: 200 \\
1: 200 \\
1: 400 \\
1: 400 \\
1: 800 \\
1: 400 \\
1: 200 \\
1: 100 \\
1: 100 \\
1: 400 \\
1: 200 \\
1: 200 \\
1: 200 \\
1: 100 \\
1: 400 \\
1: 200\end{array}$ & $\begin{array}{l}1: 200 \\
1: 200 \\
1: 100 \\
1: 400 \\
1: 400 \\
1: 200 \\
1: 100 \\
1: 200 \\
1: 200 \\
1: 200 \\
1: 100 \\
1: 100 \\
1: 100 \\
1: 200 \\
1: 200 \\
1: 200 \\
1: 400 \\
1: 200 \\
1: 800 \\
1: 400\end{array}$ & $\begin{array}{l}1: 100 \\
1: 100 \\
1: 100 \\
1: 200 \\
1: 200 \\
1: 200 \\
1: 100 \\
1: 100 \\
1: 400 \\
1: 400 \\
1: 200 \\
1: 200 \\
1: 200 \\
1: 200 \\
1: 100 \\
1: 100 \\
1: 100 \\
1: 100 \\
1: 200 \\
1: 400\end{array}$ \\
\hline $\begin{array}{c}\text { S. pyogenes } \\
2 \\
10 \\
19 \\
20 \\
31\end{array}$ & $\begin{array}{l}1: 100 \\
1: 200 \\
1: 200 \\
1: 100\end{array}$ & \begin{tabular}{|l|}
$1: 1,600$ \\
$1: 50$ \\
$1: 3.200$ \\
$1: 200$
\end{tabular} & $\begin{array}{l}1: 50 \\
1: 50 \\
1: 800\end{array}$ & $\begin{array}{l}1: 400 \\
1: 400 \\
1: 200 \\
1: 200 \\
1: 400\end{array}$ & $\begin{array}{l}1: 50 \\
1: 100 \\
1: 50 \\
1: 50 \\
1: 50\end{array}$ & $\begin{array}{l}1: 400 \\
1: 100 \\
1: 400 \\
1: 100 \\
1: 400\end{array}$ & $\begin{array}{l}1: 400 \\
1: 200 \\
1: 100 \\
1: 100 \\
1: 800\end{array}$ & \begin{tabular}{|l}
$1: 200$ \\
$1: 200$ \\
$1: 100$ \\
$1: 100$ \\
$1: 200$
\end{tabular} \\
\hline $\begin{array}{c}\text { S. anginosus } \\
11 \\
29 \\
47 \\
32 \\
42 \\
49\end{array}$ & $\begin{array}{l}1: 200 \\
1: 100 \\
1: 200 \\
1: 50 \\
1: 100\end{array}$ & $\begin{array}{l}1: 100 \\
1: 100\end{array}$ & \begin{tabular}{|l|}
$1: 1,600$ \\
$1: 3,200$ \\
$1: 100$ \\
$1: 3,200$
\end{tabular} & $\begin{array}{l}1: 400 \\
1: 200 \\
1: 200 \\
1: 200 \\
1: 800\end{array}$ & $\begin{array}{l}1: 50 \\
1: 50 \\
1: 50 \\
1: 100 \\
1: 100 \\
1: 50\end{array}$ & $\begin{array}{l}1: 800 \\
1: 100 \\
1: 100 \\
1: 200 \\
1: 200 \\
1: 200\end{array}$ & $\begin{array}{l}1: 400 \\
1: 200 \\
1: 200 \\
1: 400 \\
1: 200 \\
1: 100\end{array}$ & $\begin{array}{l}1: 200 \\
1: 200 \\
1: 200 \\
1: 200 \\
1: 200 \\
1: 200\end{array}$ \\
\hline $\begin{array}{c}\text { S. subacidus } \\
1 \\
18 \\
23 \\
25 \\
39 \\
48 \\
\end{array}$ & $\begin{array}{l}1: 200 \\
1: 100 \\
1: 100 \\
1: 200 \\
1: 100 \\
\end{array}$ & $\begin{array}{l}1: 200 \\
1: 50\end{array}$ & $\begin{array}{l}1: 50 \\
1: 50 \\
1: 50 \\
1: 100 \\
1: 100 \\
\end{array}$ & $\mid \begin{array}{c}1: 3.200 \\
1: 3,200 \\
1: \overline{3}, 200 \\
1: 3,200 \\
-\end{array}$ & $\begin{array}{c}1: 50 \\
1: 100 \\
1: 100 \\
1: 100 \\
0\end{array}$ & $\begin{array}{l}1: 100 \\
1: 200 \\
1: 200 \\
1: 200 \\
1: 200\end{array}$ & $\begin{array}{l}1: 200 \\
1: 800 \\
1: 200 \\
1: 100 \\
1: 3,200\end{array}$ & $\begin{array}{l}1: 200 \\
1: 200 \\
1: 400 \\
1: 200 \\
1: 100\end{array}$ \\
\hline $\begin{array}{l}\text { S. hemolyticus } \\
\text { No. } 2 \quad 26\end{array}$ & & $1: 200$ & $1: 100$ & $1: 200$ & $1: 3,200$ & $1: 800$ & $1: 400$ & \\
\hline $\begin{array}{c}\text { S. fecalis } \\
27 \\
40\end{array}$ & $1: 200$ & & $\begin{array}{l}1: 400 \\
1: 100\end{array}$ & $\begin{array}{l}1: 400 \\
1: 400\end{array}$ & $\begin{array}{l}1: 100 \\
1: 100\end{array}$ & \begin{tabular}{|l|} 
1:3.200 \\
$1: 3,200$ \\
\end{tabular} & $\begin{array}{l}1: 200 \\
1: 800\end{array}$ & $\begin{array}{l}1: 200 \\
1: 400 \\
\end{array}$ \\
\hline $\begin{array}{r}\text { S. mitis } \\
7 \\
9 \\
17 \\
28 \\
\end{array}$ & $\begin{array}{l}1: 200 \\
1: 200 \\
1: 200 \\
1: 100\end{array}$ & & $\begin{array}{l}1: 200 \\
1: 50 \\
1: 200 \\
1: 50 \\
\end{array}$ & $\begin{array}{l}1: 400 \\
1: 200 \\
1: 400 \\
1: 800 \\
\end{array}$ & $\begin{array}{l}1: 100 \\
1: 100 \\
1: 100 \\
1: 100\end{array}$ & $\begin{array}{l}1: 400 \\
1: 400 \\
1: 800 \\
1: 200\end{array}$ & \begin{tabular}{|l|} 
1:3,200 \\
$1: 3, \mathbf{2 0 0}$ \\
$1: 3, \mathbf{2 0 0}$ \\
1:3,200 \\
\end{tabular} & $\begin{array}{l}1: 400 \\
1: 200 \\
1: 200 \\
1: 200\end{array}$ \\
\hline S. salivar & $1: 100$ & $1: 100$ & $1: 100$ & $1: 800$ & $1: 100$ & $1: 200$ & $1: 200$ & $1: 200$ \\
\hline $\begin{array}{l}\text { S. nonhemolyticus } \\
\text { No. } 28\end{array}$ & $1: 200$ & $1: 200$ & $1: 50$ & $1: 800$ & & $1: 800$ & & $1: 3,200$ \\
\hline $\begin{array}{c}\text { S. equinus } \\
13 \\
14 \\
24\end{array}$ & & $\begin{array}{c}1: 100 \\
0 \\
1: 100\end{array}$ & 1:100 & $1: 1,600$ & $\begin{array}{l}1: 100 \\
1: 100 \\
1: 50\end{array}$ & $\begin{array}{l}1: 1,600 \\
1: 3,200 \\
1: 100\end{array}$ & $\begin{array}{l}1: 200 \\
1: 200\end{array}$ & $\begin{array}{l}1: 200 \\
1: 200 \\
1: 200\end{array}$ \\
\hline $\begin{array}{c}\text { S. ignavus } \\
12 \\
33\end{array}$ & $\begin{array}{l}1: 200 \\
1: 200\end{array}$ & & $1: 200$ & $\begin{array}{l}1: 800 \\
1: 400\end{array}$ & $\begin{array}{l}1: 50 \\
1: 100\end{array}$ & $\begin{array}{l}1: 200 \\
1: 400\end{array}$ & $\begin{array}{l}1: 200 \\
1: 400\end{array}$ & $1 \overline{1: 200}$ \\
\hline
\end{tabular}

Dilutions of antiserum were only made as high as 1:3,200. Some of the homologous combinations might have been carried still bigher, giving higher positive precipitin reactions. Homologous combinations are shown in black face type. 
Normal rabbit serum tested for precipitin content gave no reaction A significant fact is that with few exceptions the specific precipitins closely correlated with the hemolytic and fermentation reactions already mentioned. In general, when immune sera in dilutions up to $1: 1,600$ and $1: 3,200$ were added to undiluted homologous antigens flocculent precipitates were brought down, thus showing relatively specific reactions. These reactions outlined in detail in table 2 show the highest dilution of the serum in which a precipitate was observed. The antiserums were diluted instead of the antigen (precipitinogen), a reverse from the usual method for testing precipitins.

What the protein complex is in the antigen is uncertain, but we do know that it was less concentrated than the precipitin. This was shown by Gay and Chickering in the concentration of protective bodies in antipneumococcus serum; for after bringing down a maximum precipitate they could still add more antigen and obtain further precipitations. It is interesting to note that the majority of group precipitins failed to react in dilutions above 1:400 and what is of still more interest is the few exceptions as shown by table 2 among the homologous combinations. One thing quite definitely indicated is that streptococci may ultimately be divided into a number of groups with specific metabolic functions and having specific immunizing properties as shown by the results of the hemolytic, fermentative, and precipitin tests now reported.

\section{CONCLUSIONS}

Hemolytic tests of streptococci are more readily carried out by incubation in a $5 \%$ suspension of corpuscles than on blood agar.

A glucose content of over $1 \%$ in blood agar is necessary for the inhibition of hemolysis as compared with sugar-free (fermented) blood agar.

The presence of glucose in blood agar enhances the green pigment production of certain strains of streptococci.

Precipitins produced by immunizing rabbits each with one of several strains of streptococci classified by their hemolytic and fermentation reactions are relatively specific in high dilutions but also give group reactions, in most cases, however, in low dilutions.

Tricresol $(0.3 \%)$ added to antistreptococcus serum for a preservative deteriorates its precipitins.

The precipitin reaction agrees with the hemolytic and fermentative reactions in classifying streptococci. 